To Maega $\mid$ Jurnal Pengabdian Masyarakat

Bulan-Tahun, Vol. 3, No. 2, hal, 53-65

$\operatorname{ISSN}(P): 2622-6332 ; \operatorname{ISSN}(E): 2622-6340$

http://www.ojs.unanda.ac.id/index.php/tomaega

\title{
Peningkatan Keterampilan Guru IPA dalam Pengembangan Sumber Belajar Mandiri sebagai Sarana Belajar Siswa
}

\author{
Eka Putri Azrai1,a, Ade Suryanda2,b, ${ }^{\text {, }}$, Daniar Setyo Rini ${ }^{3, c}$ \\ 1, 2, 3 Program Studi Pendidikan Biologi, Fakultas Matematika danIlmu Pengetahuan Alam, \\ Universitas Negeri Jakarta \\ a,b,cEmail:ep_azrai@yahoo.com; asuryanda@unj.ac.id:daniarsetyorini@unj.ac.id \\ *Correspondent Email: asuryanda@unj.ac.id
}

Article History:

Received: 21-02-2020; Received in Revised: 13-06-2020; Accepted: 19-06-2020

DOI: http://dx.doi.org/10.35914/tomaega.v3i2.313

\begin{abstract}
Abstrak
Perubahan paradigma dalam pembelajaran merupakan keniscayaan. Perubahan terjadi dalam desain, proses dan dan penilaian dalam pembelajaran. Perubahan menuntut guru mempersiapkan diri dengan berbagai ketrampilan, salah satunya ketrampilan pengembangan sumber belajar. Sumber belajar yang dikembangkan guru tentunya memiliki keunggulan dibandingkan dengan sumber belajar yang sudah tersedia seperti buku paket. Tujuan dari kegiatan pengabdian ini adalah untuk meningkatkan motivasi, pengetahuan dan ketrampilan guru dalam pengembangan sumber belajar yang dapat digunakan dalam belajar mandiri. Kegiatan pengabdian ini menggunakan metode experiential learning dengan pendekatan participant-centered melalui teknik case study, dan simulasi, dilanjutkan dengan praktek pengembangan sumber belajar dengan pendampingan oleh tim pengabdian pada Masyarakat. Luaran dari kegiatan ini adalah peningkatan motivasi, pemahaman dan ketrampilan guru-guru IPA MTs se Kabupaten Bogor dan berhasilnya guru mengembangkan produk sumber belajar yang digunakan dalam pembelajaran.
\end{abstract}

Kata Kunci: experiential learning; keterampilan guru; sumber belajar.

\begin{abstract}
The change in paradigm in learning is a necessity. Changes occur in the design, process and assessment of learning. Change requires teachers to prepare themselves with various skills, one of which is the development of learning resources. Learning resources developed by teachers certainly have advantages compared to learning resources that are already available such as textbooks. The purpose of this community service activity is to increase the motivation, knowledge and skills of teachers in developing learning resources that can be used in independent learning. This community service uses the experiential learning method with a participant-centered approach through case study techniques, and simulations, followed by the practice of developing learning resources with mentoring by the community service team. The output of this activity is increasing motivation, understanding and skills of MTS IPA teachers in Bogor Regency and the success of teachers in developing learning resource products that are used in learning.
\end{abstract}

Key Word: experiential learning; learning resources; teacher skills. 


\section{Pendahuluan}

Perubahan paradigma dalam pembelajaran menjadi suatu hal yang banyak dibahas saat ini. Hal yang mendasari perubahan paradigma pembalajaran itu adalah tuntutan pembelajaran abad ke 21. Keterampilan berpikir kritis, pemecahan masalah, metakognisi, keterampilan berkomunikasi, berkolaborasi, inovasi dan kreasi, literasi informasi, merupakan keterampilan di abad ke-21 yang penting dan relevan dengan empat pilar kehidupan yang mencakup learning to know, learning to do, learning to be dan learning to live together (Delors, 2013; UNESCO, 2014). Diharapkan pendidikan dapat mempersiapkan siswa untuk menguasai berbagai keterampilan tersebut agar menjadi pribadi yang sukses dalam hidup.

Pada umumnya diakui bahwa kompetensi dan keterampilan abad ke-21 yang kompleks dan menantang untuk dipelajari sangat diperlukan, namun siswa tidak mengembangkannya kecuali mereka secara eksplisit diajarkan (Zubaidah, 2016). Yang bertanggungjawab mengajarkan ini tentunya para guru. Seiring dengan perubahan paradigm dan ketrampilan abad 21 perlu diajarkan pada para siswa maka tugas dan peranan juga mengalami pergeseran. Guru dituntut memiliki ketrampilan yang lebih dibandingkan dengan pembelajaran sebelumnya. Guru merupakan ujung tombak pendidikan sebagai sosok yang bertanggungjawab langsung dalam meningkatkan kualitas pendidikan melalui peningkatan kualitas pembelajaran (Azrai \& Refirman, 2013; A. Suryanda, Sartono, \& Sa'diyah, 2019; Ade Suryanda, Azrai, \& Julita, 2019; Ade Suryanda, Azrai, \& Julta, 2020). Peran guru dalam abad 21 harus bergeser dari "penanam pengetahuan", menuju peran sebagai pembimbing, pengarah diskusi dan pengukur kemajuan belajar siswa (Hampson, Patton, \& Shanks, 2017). Memenuhi tuntutan abad 21 maka perlu perubahan dalam sistem pendidikan yang berdampak nyata pada proses pembelajaran di sekolah.

Pemerintah menyikapi dengan pembaharuan terhadap kurikulum dan pembaharuan dalam pembelajaran. Implementasi kurikulum 2013 menekankan pada ketrampilan proses dengan lima pengalaman belajar pokok yaitu: mengamati, menanya, mengumpulkan informasi, mengasosiasi, dan mengkomunikasikan. Implementasi kurikulum ini berdampak pada perubahan proses pembelajaran. Tidak terkecuali pada pembelajaran IPA.

Dalam praktek riil di lapangan, ada beberapa kendala yang dialami guru ketika menerapkan kurikulum 2013, salah satunya tentang waktu. Hal ini sejalan dengan kenyataan bahwa kurikulum 2013 menuntut dilaksanakannya pembelajaran aktif dan penilaian otentik yang pelaksanaannya memerlukan waktu lebih lama dibandingkan pembelajaran yang berpusat pada guru dan penilaian konvensional (Nurdyansyah \& Fahyuni, 2016). Menyiasati kendala waktu ini salah satu hal yang dapat dilakukan guru adalah mengembangkan kegiatan pembelajaran yang tidak hanya terjadi dalam jam tatap muka. Siswa harus dilatih untuk belajar secara mandiri. 
Belajar mandiri berarti siswa belajar tanpa didampingi oleh guru. Supaya pembelajaran mandiri dapat berlangsung dengan efektif maka guru harus mampu mendisain tugas belajar yang tepat serta mempersiapkan sumber belajar yang dapat memudahkan siswa dalam proses belajarnya. Sumber belajar diperlukan di mana saja dan kapan saja belajar itu dibutuhkan (Sitepu, 2014).

Sumber belajar adalah segala sesuatu yang terdapat di sekitar lingkungan kegiatan belajar secara fungsional dapat digunakan untuk optimalisasi hasil belajar. Januszewski \& Molenda, (2010) menjelaskan mengenai sumber belajar merupakan semua sumber termasuk pesan, orang, bahan, alat, teknik, anggaran, fasilitas, dan latar yang dapat dipergunakan peserta didik baik secara sendirisendiri maupun dalam bentuk gabungan untuk menfasilitasi kegiatan belajar dan meningkatkan kinerja belajar. Sumber belajar bisa termasuk apa saja yang tersedia untuk membantu seseorang belajar, meliputi lingkungan fisik, seperti tempat belajar, bahan dan alat yang dapat digunakan, personal seperti guru, petugas perpustakaan dan ahli media serta siapa saja yang berpengaruh baik langsung maupun tidak langsung untuk keberhasilam pengalaman belajar (Prastowo, 2018; Sanjaya, 2016). Agar dapat membantu proses pembelajaran secara efektif, sumber belajar harus selaras dan sesuai dengan kebutuhan tugas pembelajaran dan kemampuan mental siswa (Abdullah, 2012).

Banyak bentuk sumber belajar yang dapat digunakan. Sumber belajar dapat dikelompokan berdasarkan bentuknya dan berdasarkan perancangannya. Berdasarkan ujudnya sumber belajar dapat berupa tercetak dan noncetak, Berdasarkan perancangannya sumber belajar dibedakan atas sumber belajar yang dirancang (by designed) dan sumber belajar yang tinggal pakai (by utilization)." Sumber belajar yang dirancang (by designed) berupa sumber belajar yang dikembangkan dan diproduksi untuk pembelajaran, sedangkan sumber belajar by ulilization merupakan sumber belajar yang sudah ada dan dimanfaatkan untuk pembelajaran. Sumber belajar juga dapat dibedakan berdasarkan cara memperoleh informasinya yaitu jenis visual, audio dan audiovisual (Sitepu, 2014).

Sumber belajar yang sesuai dengan kebutuhan para siswa, tentunya harus dikembangkan oleh guru. Keunggulan sumber belajar yang dikembangkan guru lebih sesuai dengan kondisi siswa, meningkatkan kompetensi profesional dan pedagogik guru. (Prastowo, 2018) mengungkapkan bahwa sekarang ini sumber belajar yang dirancang atau didesain lebih banyak dan dapat digunakan guru dalam proses pembelajaran

Banyak ragam sumber belajar yang dapat dikembangkan oleh para guru. Sumber belajar bisa berupa cetak, e-book dan lain-lain. Bahkan dengan perkembangan tekhnologi sekarang para guru punya ruang untuk memanfaatkan tekhologi yang ada sebagai basis sumber belajar (Ferliyati, Kurniati, \& Suryanda, 2014; Komala, Suryanda, \& Lismana, 2016; Suryanda, Sartono, \& Sa'diyah, 2019; Suryanda, Ernawati, \& Maulana, 2018; Suryanda, Rusdi, \& Kusumawati, 2017).

(C)To Maega / Jurnal Pengabdian Masyarakat. This is an open access article under the CC BY-SA 4.0 license (https://creativecommons.org/licenses/by-sa/4.0/). 
Guru berkualitas adalah yang memiliki pengaruh kuat terhadap prestasi siswa (Zubaidah, 2016). Sekalipun teknologi di era digital berkembang sangat pesat, namun peran guru dan tenaga kependidikan masih tetap tidak tergantikan. Dalam hal ini guru justru dapat memanfaatkan era digital (information literacy) tersebut untuk memperkaya sumber belajar bagi para siswanya (Didiharyono \& Qur'ani, 2019).

Guru professional harus memiliki 4 kompetensi, yaitu kompetensi professional, kompetensi pedagogic, kompetensi social dan kompetensi personal. Berkenaan dengan kompetensi pedagogik, seorang guru tidak hanya harus paham tentang teori belajar dan pembelajaran tetapi juga dituntut untuk mahir dalam penerapan dalam pembelajaran. Salah satu ketrampilan yang mesti dimiliki guru adalah ketrampilan dalam mengembangkan sumber belajar bagi para siswanya.

Permasalahan di lapangan ternyata guru lebih banyak memilih menggunakan sumber belajar yang tersedia. Sedikit guru yang mau mengembangkan sendiri sumber belajar yang akan digunakan dalam pembelajarannya (Wijaya \& Nurhadi, 2020). Hal ini dimungkinkan karena pengetahuan guru yang memang terbatas tentang sumber belajar dan juga kemampuan guru yang lemah dalam pengembangan pembelajaran. Perlu suatu program yang dapat mengatasi permasalahan ini. Dalam program ini bermitra dengan guru-guru MTs kabupaten Bogor.

Berdasarkan hasil identifikasi yang dilakukan permasalahan yang dihadapi guru-guru MTs di kabupaten Bogor ini meliputi

1. Terbatasnya waktu yang tersedia untuk pembelajaran tatap muka

2. Anggapan siswa terhadap mata pelajaran IPA

3. Tuntutan pembelajar yang makin komplek

4. Keterbatasan pemahaman guru dalam pengembangan sumber belajar

5. Guru terbiasa hanya menggunakan sumber belajar yang sudah tersedia, seperti buku paket

6. Guru tidak termotivasi untuk mengembangkan sendiri sumber belajar yang digunakan dalam pembelajarannya

7. Guru tidak terlatih untuk mengembangkan bahan ajar

Mengacu ke permasalahan yang teridentifikasi dilakukan penjajakan awal ke mitra. Dan dari hasil penjajagan disepakati suatu kegiatan yang terfokus pada masalah peningkatan pemahaman dan kemampuan guru dalam mengembangkan sumber belajar. Bentuk kegiatan berupa pelatihan dan pendampingan bagi guruguru dalam mengembangakan sumber belajar. Sumber belajar yang dikembangkan merupakan sumber belajar mandiri dan sumber belajar pengayaan. Permasalahan yang menjadi fokus kegiatan dapat dirinci menjadi beberapa pertanyaan sebagai berikut:

1. Bagaimanakah tingkat pemahaman guru tentang sumber belajar?

2. Bagaimana peningkatan motivasi guru dalam mengembangkan sumber belajar 
3. Bagaimana peningkatan kemampuan guru dalam mengembangkan sumber belajar?

Diharapkan diakhir kegiatan terjadi peningkatan pemahaman guru tentang sumber belajar, guru termotivasi untuk mengembangkan sumber belajar yang akan digunakan dalam pembalajaran yang dikelola dan terjadi peningkatan kemampuan guru dalam mengembangkan sumber belajar.

\section{Metode}

Metode pelaksanaan kegiatan peningkatan ketrampilan guru dalam pengembangan sumber belajar mandiri dan sumber belajar pengayaan ini menerapkan metode pembelajaran pengalaman (experiential learning). Metode ini merupakan suatu proses refleksi pengalaman yang dapat menimbulkan gagasan atau pengetahuan baru. Dalam hal ini guru-guru yang mengikuti kegiatan diajak berdiskusi untuk menggali pengalamannnya selama ini dalam mengelola pembelajaran, mengungkap permasalahan serta ide-ide mereka dalam mengatasi permasalahan tersebut. Pemberian informasi dari nara sumber akan ikut menambah wawasan peserta. Dari proses ini peserta kegiatan akan membentuk konsep-konsep abstrak yang kemudian dicobakan pada berbagai situasi baru, sehingga memberikan suatu pengalaman baru lagi bagi individu, demikian seterusnya proses pembelajaran berlangsung, seperti sebuah siklus (Achmat, 2006).

Peran nara sumber dalam kegiatan menggunakan model experiential learning, adalah sebagai fasilitator, yang berfungsi sebagai pengarah dan perancang pengalaman belajar. Narasumber harus mengkondisikan situasi supaya prosese belajar peserta dapat terfasititasi. Peserta pelatihan memperoleh pengalaman baru atau terbantu menata pengalamannya di masa lampau dengan cara baru (Achmat, 2006).

Program pelatihan ini lebih banyak melibatkan aktifitas peserta melalui diskusi, tanyajawab, brainstorming, observasi, bermain peran (role-play). Pelibatan peserta secara aktif ditujukan supaya peseta tidak bosan dan tidak merasa digurui (Fowlie \& Wood, 2009; Fowlie, J., 2000). Untuk menjamin keberlanjutan program, menjalin kerjasama dan komunikasi dengan para guru. Program ini diharapkan menjadi agenda rutin MGMP. Para guru yang telah ikut kegiatan diharapkan dapat menularkan ketrampilan ke guru-guru lainnya.

\section{Hasil dan Pembahasan}

Kegiatan pengabdian kepada masyarakat (PKM) dari program studi pendidikan biologi Universitas Negeri Jakarta telah selesai dilaksanakan. Salah satu kegiatan PKM yang dilaksanakan adalah workshop mengenai sumber belajar mandiri sebagai sarana belajar siswa. Kegiatan workshop ini diikuti oleh guruguru IPA MTs di wilayah kabupaten Bogor, Jawa Barat sebanyak 69 orang dari 
[ 58 ] Eka Putri Azrai, dkk / To Maega : Jurnal Pengabdian Masyarakat, Vol. 3; No.2; Agustus, 2020

target peserta sebanyak 50 orang. Adapun detil data karakteristik peserta dapat dilihat dalam Tabel 1 berikut.

Tabel 1. Data Karakteristik Peserta Wokshop

\begin{tabular}{lc}
\hline \multicolumn{1}{c}{ Karakteristik Peserta } & Frekuensi (dalam \%) \\
\hline Usia & 36 \\
\hline $20-30$ tahun & 24 \\
\hline $31-40$ tahun & 28 \\
\hline $41-50$ tahun & 12 \\
\hline$>50$ tahun & 26 \\
\hline Masa Kerja & 30 \\
\hline $0-3$ tahun & 28 \\
\hline $5-10$ tahun & 16 \\
\hline $10-15$ tahun & 0 \\
\hline $15-20$ tahun & 0 \\
\hline$>20$ tahun & \\
\hline \multicolumn{1}{c}{ Jumlah sumber belajar yang digunakan dalam setiap proses pembelajaran } \\
\hline 1 macam & 12 \\
\hline $1-3$ macam & 68 \\
\hline$>3$ macam & 20 \\
\hline
\end{tabular}

Berdasarkan data di atas terlihat bahwa guru IPA MTs di wilayah kabupaten Bogor memiliki rentang usia terbanyak pada usia 20-30 tahun dengan masa kerja terbanyak pada 5-10 tahun. Data ini menunjukkan bahwa guru IPA di wilayah tersebut tengah memasuki masa kerja dan usia produktif. Sehingga, memiliki peluang besar untuk dapat dijadikan sebagai objek binaan kegiatan pengabdian masyarakat. Didukung oleh antusiasme peserta yang cukup besar untuk kegiatan workshop ataupun pelatihan ini.

Kegiatan dimulai dengan paparan dari tim pelaksana PKM mengenai sumber belajar mandiri. Sumber belajar mandiri dapat disajikan dalam berbagai macam baik cetak maupun elektronik. Paparan dari tim pelaksana menekankan kepada peserta bahwa dengan kemajuan teknologi saat ini, guru lebih banyak memiliki peran yang bebas untuk dapat membuat sumber belajarnya sendiri secara mandiri, tidak hanya memanfaatkan sumber belajar yang ada.

Sumber belajar yang menarik dapat diberikan dengan menggunakan media pembelajaran yang menarik pula. Selama kegiatan PKM, tim pelaksana memaparkan beberapa contoh media pembelajaran sederhana yang dapat dibuat dan dikreasikan sendiri oleh guru di sekolah dan dapat dijadikan sebagai sumber belajar. Media dapat dibuat dengan menggunakan alat-alat sederhana seperti dalam bentuk kartu kuartet, permainan ular tangga ataupun media pembelajaran sederhana lainnya yang bertujuan untuk mengasah mind on siswa dalam pembelajaran. Selain mind on, proses pembelajaran IPA juga membutuhkan hands on atau kegiatan praktikum. 
Pada sekolah dengan fasilitas laboratorium yang kurang memadai, hal ini juga bisa disiasati dengan menggunakan media pembelajaran. Seperti yang saat ini sedang banyak dibuat adalah virtual laboratorium dengan menggunakan aplikasiaplikasi tertentu. Setelah mendengar pemaparan dari tim pelaksana, peserta diminta untuk berkelompok dan kemudian berdiskusi mengenai sumber belajar mandiri yang dapat diterapkan dalam proses pembelajaran.

Secara keseluruhan kegiatan PKM telah berjalan lancar sesuai dengan yang direncanakan. Adapun survei evaluasi mengenai kegiatan workshop PKM ini dapat dilihat dalam Gambar 1. Berdasarkan hasil survei terlihat bahwa peserta merasa bahwa kegiatan workshop telah membantu mereka untuk mendapatkan update informasi baru mengenai sumber belajar dan memotivasi mereka untuk dapat membuat sumber belajar mandiri di kegiatan pembelajaran kelas mereka masing-masing. Hal ini terlihat dari jawaban peserta yang menyatakan setuju dan sangat setuju dengan jumlah lebih dari 50\%. Materi workshop yang disampaikan juga dinilai relevan dan mudah untuk diterapkan di sekolah masing-masing karena tidak membutuhkan fasilitas khusus dalam penerapannya. Kegiatan workshop ini juga dinilai membantu peserta dalam memberikan ide-ide baru terkait pembuatan sumber belajar mandiri dan media pembelajaran sederhana.

Secara keseluruhan kegiatan PKM dinilai telah memberikan kepuasan yang baik kepada peserta. Walaupun masih ada kekurangan dalam hal alokasi waktu diskusi belum cukup lama. Berdasarkan hasil survei didapatkan bahwa $100 \%$ peserta menyatakan "ya" untuk kebutuhan mereka dalam mendapatkan ilmu melalui kegiatan workshop seperti ini. Peserta juga 100\% menyatakan "ya" dalam mendukung kegiatan lanjutan dari kegiatan PKM ini. Peserta menyarankan untuk dapat melaksanakan kegiatan workshop seperti ini lebih dari 3 kali dalam 1 tahun. Adapun materi yang mereka harapkan dapat diadakan dalam kegiatan workshop diantaranya mengenai media pembelajaran, penilaian autentik, pendalam materi biologi dan fisika di SMP/MTs dan bagaimana menjadi guru yang kreatif. Adapun hasil survei kepuasan pelaksanaan kegiatan workshop dapat dilihat pada Gambar 1 berikut. 
Kerja praktik dalam kelompok memudahkan saya dalam memahami materi dan memunculkan ide-ide baru.

Kerja praktik dalam kelompok memudahkan saya dalam memahami materi dan memunculkan ide-ide baru.

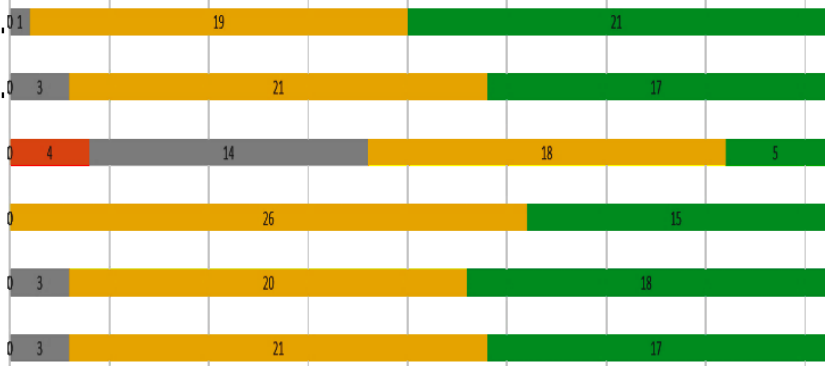

Secara keseluruhan diskusi/tanya-jawab telah sangat membantu meningkatkan pemahaman saya sebagai. Pemateri memberikan jawaban terhadap pertanyaan peserta dengan baik Alokasi waktu untuk diskusi mencukupi untuk menambah/memperkuat pemahaman saya Pemateri menyampaikan isi materi dengan baik, mudah dimengeti dan memberikan contoh-contoh. Alokasi waktu penyampaian materi mencukupi Pematerisangat memahami materi yang disampaikan Saya merasa lebih mudah dalam membuat sumber belajar setelah mendapatkan informasi dari workshop. Materi yang disampaikan membantu saya dalam memberikan ide-ide baru untuk menyusun sumber belajar. Materi yang disampaikan dapat diterapkan dalam proses pembelajaran di sekolah słya nanti Materi yang disampaiken relevan dan telah sesuai dengan yang diharapken. Setelah mengikuti workshop, Saya memperoleh ilmu pengetahuan baru mengenai sumber belajar mandiri. Secara keselunuhan Saya puas dengan penyampaian materi pada workshop kali ini.

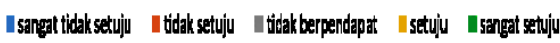

Gambar 1. Grafik Survei Kepuasan Workshop Sumber Belajar IPA

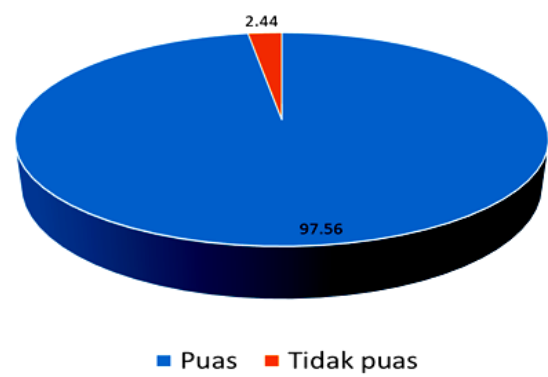

Gambar 2. Tingkat Kepuasan Peserta Workshop

Setelah kegiatan workshop dilakukan diadakan kegiatan pendampingan selama 2 minggu untuk kemudian dilihat hasil produk sumber belajar yang dibuat oleh para peserta. Berdasarkan kegiatan survei sederhana setelah kegiatan pendampingan, beberapa peserta membuat beberapa contoh sumber belajar yang 
[ 61 ] Eka Putri Azrai, dkk / To Maega : Jurnal Pengabdian Masyarakat, Vol. 3; No.2; Agustus, 2020

digunakan di dalam kelas. Adapun produk hasil yang dibuat oleh peserta workshop dapat dilihat dalam tabel berikut,

Tabel 2. Dokumentasi Produk Hasil Pendampingan Sumber Belajar sederhana dalam pembelajaran IPA

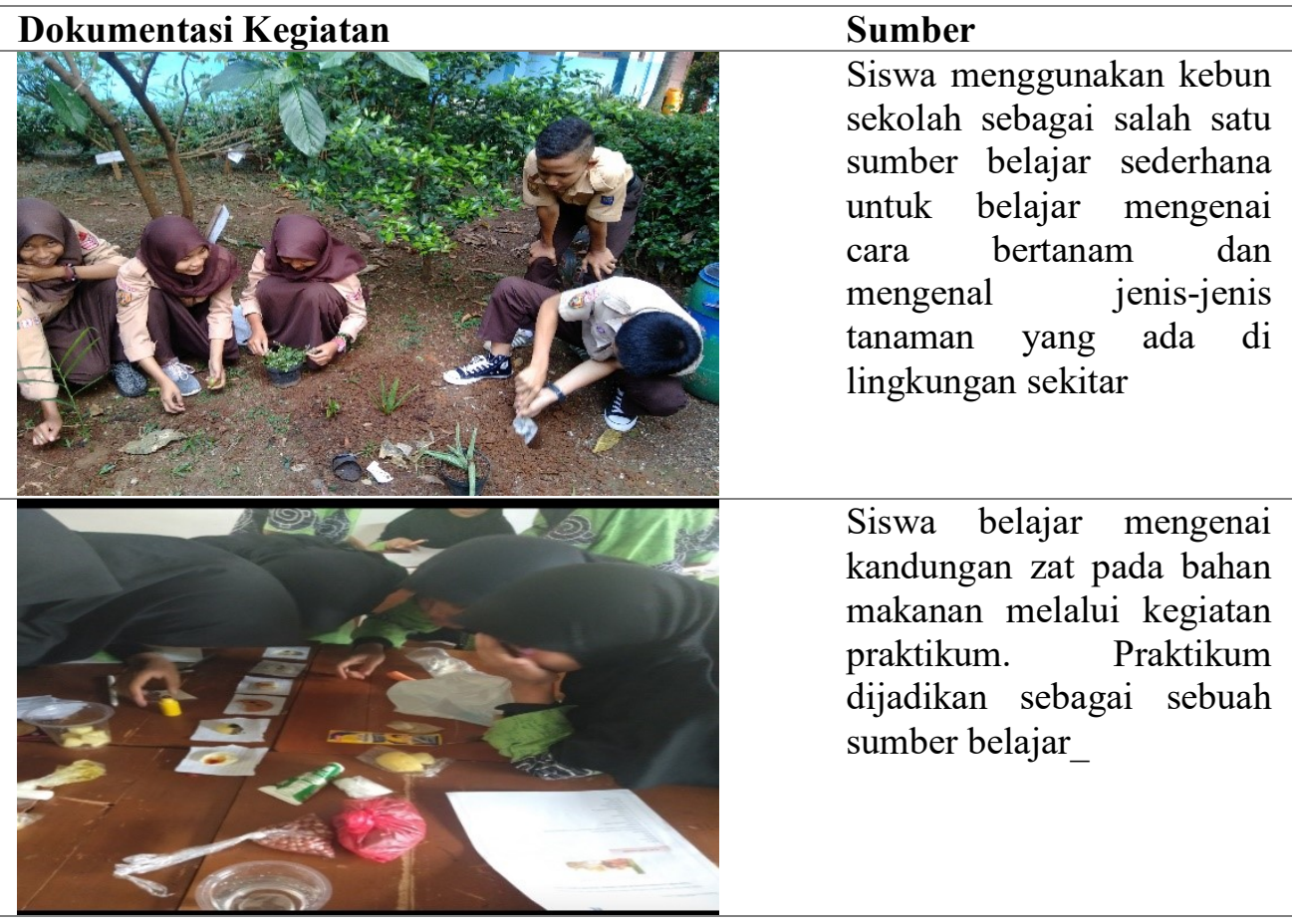

Survei sederhana juga dilakukan tim pelaksana setelah kegiatan pendampingan selesai dilaksanakan. Survei bertujuan untuk mengetahui sejauh mana peserta memahami dan dapat mengaplikasikan hasil workshop dalam proses pembelajaran setiap harinya. Gambar 3 berikut memaparkan mengenai hasil survei setelah kegiatan pendampingan dilaksanakan. 


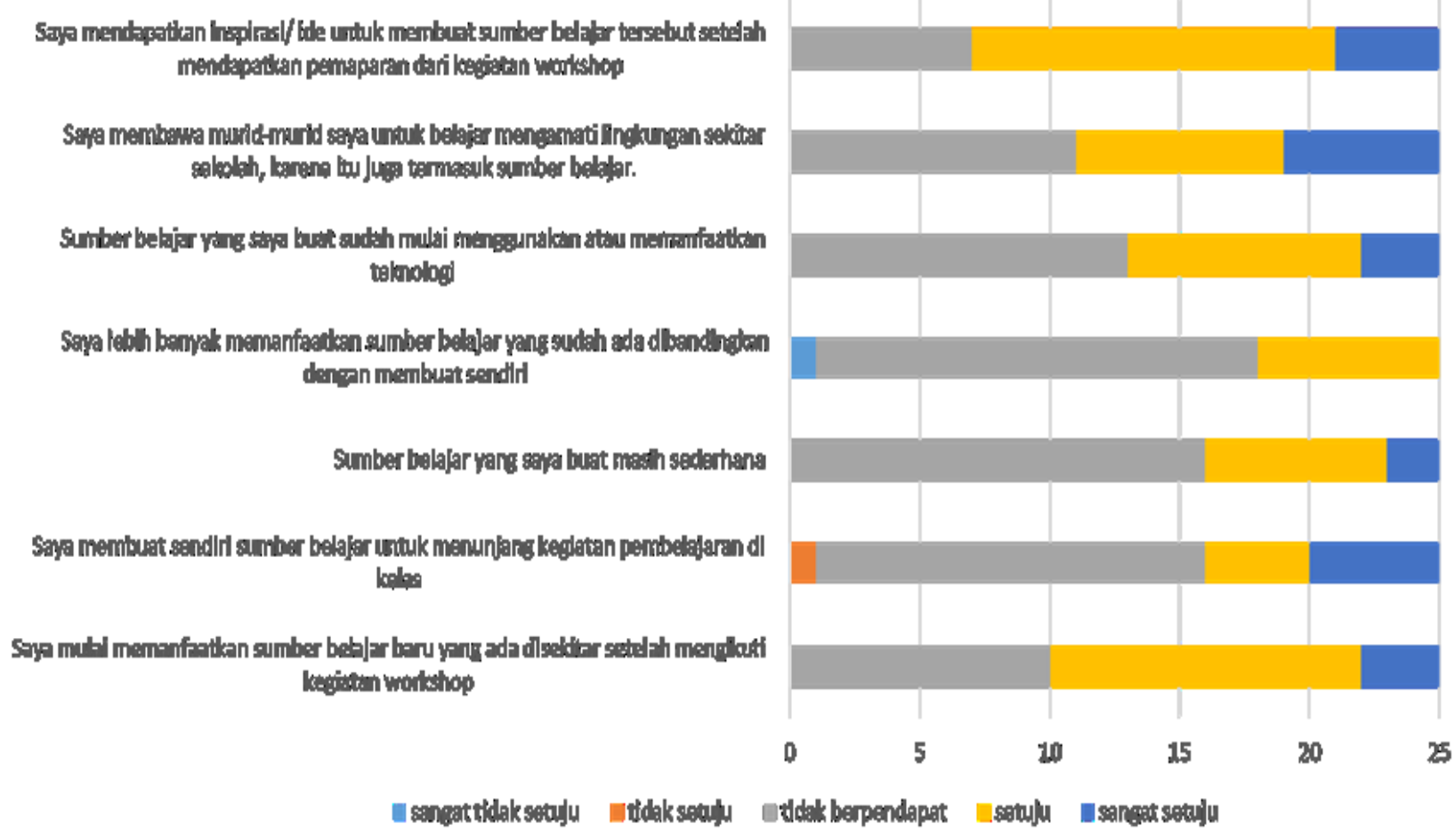

Gambar 3. Hasil Survei Setelah Kegiatan Pendampingan

Berdasarkan grafik di atas terlihat bahwa jawaban tidak berpendapat memiliki kecenderungan lebih banyak disusul dengan jawaban setuju. Hal ini mengindikasikan bahwa peserta setelah kegiatan workshop sebagian besar belum mengaplikasikan ilmu yang didapatkan. Hal ini didukung oleh kegiatan pendampingan yang dirasa juga belum berjalan maksimal. Tim pelaksana mengalami kesulitan dalam melakukan kegiatan pendampingan dikarenakan peserta yang berasal dari banyak sekolah sehingga untuk melakukan kegiatan diskusi dalam kelompok menjadi lebih sulit. Sehingga, kegiatan pendampingan dilakukan secara individual dan beberapa peserta masih memiliki motivasi yang cukup rendah untuk dapat melakukan kegiatan tersebut. Solusi yang ditawarkan berdasarkan kendala yang terjadi mungkin dapat dilakukan kegiatan workshop beserta pendampingan dalam kurun waktu yang lebih lama dengan mekanisme karantina. Sehingga, pemaparan ilmu yang diberikan bisa secara efektif diterima. Kemudian juga, proses pemberian materi mungkin dapat dilakukan dengan cara yang lebih memotivasi. Sehingga guru secara sukarela dapat mengimplementasikan ilmu yang telah di dapat tersebut dalam proses pembelajaran mereka masing-masing setiap harinya. Apabila kegiatan ini dapat dilakukan dalam waktu yang berkesinambungan, mulai dari materi yang sederhana sampai dengan materi yang komplek untuk mendukung kemajuan pembelajaran di Era industry 4.0 maka hasil yang maksimal diharapkan dapat diperoleh. 

2020

\section{Kesimpulan}

Workshop peningkatan keterampilan guru IPA dalam pengembangan sumber belajar mandiri sebagai sarana belajar siswa telah terlaksana dengan baik. Peserta mampu menerima materi dengan baik, mengikuti proses kegiatan dan antisius selama kegiatan. Secara keseluruhan hasil menunjukkan: (1) meningkatnya pemahaman peserta tentang sumber belajar mandiri dan termotivasi untuk mengembangkannya; (2) meningkatnya keterampilan peserta dalam mengembangkan sumber belajar sederhana yang dapat membantu siswa belajar lebih baik. Minimnya kegiatan serupa yang didapati oleh peserta, maka berdasarkan hasil kegiatan disarankan kegiatan pengembangan potensi dan kompetensi guru perlu ditingkatkan dan rutin diadakan, baik oleh pihak sekolah maupun komunitas guru (MGMP). Curah pendapat dan saling tukar pengalaman, merupakan satu aktivitas guru yang sangat disarankan diterapkan di semua sekolah oleh seluruh guru, untuk selalu menjaga peningkatan kompetensi.

\section{Ucapan Terimakasih}

Ucapan terimakasih kami sampaikan kepada guru-guru IPA MTs se-kabupaten Bogor yang sudah terlibat aktif dalam kegiatan pengabdian ini.

\section{Daftar Pustaka}

Abdullah, R. (2012). Pembelajaran Berbasis Pemanfaatan Sumber Belajar. Jurnal Ilmiah Didaktika, 12(2), 216-231. https://doi.org/10.22373/jid.v12i2.449

Achmat, Z. (2006). Efektifitas Pelatihan Pengembangan Kepribadian dan Kepemimpinan dalam Meningkatkan Kepercayaan Diri Mahasiswa Baru UMM Tahun 2005 / 2006. Humanity, 1(2), 117-121.

Azrai, E. P., \& Refirman. (2013). Efektifitas Penerapan E- book sebagai Sumber Belajar Mandiri dalam Pembelajaran Biologi. Semirata FMIPA Universitas Lampung, 243-250. Lampung.

Delors, J. (2013). The treasure within: Learning to know, learning to do, learning to live together and learning to be. What is the value of that treasure 15 years after its publication? International Review of Education, 59(3), 319-330. https://doi.org/10.1007/s11159-013-9350-8

Didiharyono, D., \& Qur'ani, B. (2019). Increasing Community Knowledge Through the Literacy Movement. To Maega : Jurnal Pengabdian Masyarakat, 2(1), 17-24. https://doi.org/10.35914/tomaega.v2i1.235

Ferliyati, L., Kurniati, T. H., \& Suryanda, A. (2014). Penggunaan Multimedia Interaktif Berbasis Inkuiri dalam Meminimalisasi Miskonsepsi Siswa pada Materi Bioteknologi. Biosfer : Jurnal Pendidikan Biologi, VII(1), 17-25.

Fowlie, J., \& Wood, M. (2009). The emotional impact of leaders' behaviours. Journal of European Industrial Training, 33(6), 559-572. https://doi.org/10.1108/03090590910974428

Fowlie, J. (2001). Emotional intelligence: the role of self-confidence in preparing business school undergraduates for placement/employment. In 2nd Annual 
[ 64 ] Eka Putri Azrai, dkk / To Maega : Jurnal Pengabdian Masyarakat, Vol. 3; No.2; Agustus, 2020

Skills Conference Hatfield, UK Duration: 1 July 2001. https://research.brighton.ac.uk

Hampson, M., Patton, A., \& Shanks, L. (2017). Ideas for 21st Century Education (J. Craig \& M. Horne, eds.). Retrieved from https://www.innovationunit.org/publications/10ideasfor21 centuryeducation/

Januszewski, A., \& Molenda, M. (2010). Educational Technology: A Definition with Commentary (Vol. 12). New York: Routledge.

Komala, R., Suryanda, A., \& Lismana, D. D. (2016). Pengembangan Paludarium sebagai Media Pembelajaran Biologi Pokok Bahasan Ekosistem di SMA. BIOSFER Jurnal Pendidikan Biologi, 9(1), 10-14. https://doi.org/https://doi.org/10.21009/biosferjpb.9-1.2

Nurdyansyah, \& Fahyuni, E. F. (2016). Inovasi Model Pembelajaran. Sidoarjo: Nizamia Learning Center.

Prastowo, A. (2018). Sumber Belajar dan Pusat Sumber Belajar Teori dan Aplikasinya di Sekolah/Madrasah. Depok: Prendadamedia Grup.

Sanjaya, W. (2016). Media komunikasi Pembelajaran (Pertama). Jakarta: Kencana Prenada Media Group.

Sitepu, B. P. (2014). Pengembangan Sumber Belajar. Jakarta: Rajawali Pers.

Suryanda, A., Sartono, N., \& Sa'diyah, H. (2019). Developing smartphone-based laboratory manual as a learning media. Journal of Physics: Conference Series, 1402(7). https://doi.org/10.1088/1742-6596/1402/7/077077

Suryanda, A., Sartono, N., \& Sa'Diyah, H. (2019). Developing smartphone-based laboratory manual as a learning media. Journal of Physics: Conference Series, 1402(7). https://doi.org/10.1088/1742-6596/1402/7/077077

Suryanda, A., Azrai, E. P., \& Julita, A. (2019). Expert Validation on The Development Biology Pocketbook Based on Mind Map ( BIOMAP ). Biodik: Jurnal Ilmiah Pendidikan Biologi, 5(3), 197-214. https://doi.org/https://doi.org/10.22437/bio.v5i3.6879

Suryanda, A., Azrai, E. P., \& Julta, A. (2020). Analisis Kebutuhan Pengembangan Buku Saku Biologi Berbasis Mind Map (BIOMAP). Jurnal Pendidikan Matematika Dan IPA, 11(1), 86-98. https://doi.org/dx.doi.org/10.26418/jpmipa.v11i1.31861

Suryanda, A., Ernawati, E., \& Maulana, A. (2018). Pengembangan Modul Multimedia Mobile Learning Dengan Android Studio 4.1 Materi Keanekaragaman Hayati Bagi Siswa Sma Kelas X. Biosfer: Jurnal Pendidikan Biologi, 9(1), 55-64. https://doi.org/10.21009/biosferjpb.9-1.9

Suryanda, A., Rusdi, \& Kusumawati, D. (2017). Pengembangan Praktikum Virtual Urinalisis sebagai Media Pembelajaran Biologi Siswa SMA Kelas XI. Biosfer: Jurnal Pendidikan Biologi, 10(1), 1-8. https://doi.org/https://doi.org/10.21009/biosferjpb.10-1.1

UNESCO. (2014). Learning to Live together. In UNESCO Bangkok Office (Vol. 60). https://doi.org/10.1016/j.soin.2015.08.020

Wijaya, T., \& Nurhadi. (2020). Peningkatan Kemampuan Pengolahan Data Melalui Pelatihan Statistik dan Aplikasi Program SPSS bagi Guru-Guru SMA di DIY. To Maega | Jurnal Pengabdian Masyarakat, 3(1), 31-33. 
[65] Eka Putri Azrai, dkk / To Maega : Jurnal Pengabdian Masyarakat, Vol. 3; No.2; Agustus, 2020

https://doi.org/http://dx.doi.org/10.35914/tomaega.v3i1.293

Zubaidah, S. (2016). Keterampilan Abad Ke-21: Keterampilan Yang Diajarkan Melalui Pembelajaran. Seminar Nasional Pendidikan, 1-17. Sintang: Program Studi Pendidikan Biologi STKIP Persada Khatulistiwa. 